5. Борисова, О.О. Питание спортсменов: зарубежный опыт и практические рекомендации [Текст]: Учебно- методическое пособие / О.О. Борисова. - М.: Советский спорт, 2007. - 132 c.

6. Павлова, Ю., Виноградський, Б. Відновлення у спорті [Текст]: монографія / Ю. Павлова, Б. Виноградський. - Л.: ЛДУФК, 2011. - 204 c.

7. Батырев, М.Е. Спортивное питание [Текст] / М.Е. Батырев, Т.Ф. Батырева. - СПб: Питер, 2005. - 144 c.

8. Карелин, А.О. Правильное питание при занятиях спортом и физкультурой [Текст] / А.О. Карелин. - СПб.: Диля, 2005. $-256 c$.

9. Бойко, Е.А. Питание и диета для спортсменов [Текст] / Е.А. Бойко. - М.: Вече, 2006. - 176 c.

10. Матвеева, Ж.Н. Рациональное питание и использование восстановительных мероприятий при повышенных физических нагрузках. Контроль за весом тела [Текст] / Ж.Н. Матвеева. - Новгород: МО и ОРФ, НГУ им. Ярослава Мудрого, 1999. - 25 c.

11. Хэтфилд, Фредерик К. Всестороннее руководство по развитию силь [Текст] / Фредерик К. Хэтфилд. - Красноярск: Издано ассоџиаџией федераџий культуризма Восточной Сибири и Дальнего Востока "Восток", 1992. - 288c.

12. Лиходеева, В.А. Особенности адаптации и обмена веществ при мышечной деятельности [Текст]: учебное пособие для студентов / В.А. Лиходеева. - Волгоград, 2004. - 31 с.

13. Пшендин, П.И. Рациональное питание спортсменов [Текст] / П.И. Пшендин. - М.: Фи С, 2005. - 74 с.

14. Удалов, Ю.Ф. Биохимия мышечной деятельности [Текст]: учебное пособие / Ю.Ф. Удалов, Л.П. Михеева. - Малаховка: МГАФК, 2005. - $236 \mathrm{c}$.

15. Шестопалов, С.В. Бодибилдинг [Текст] / С.В. Шестопалов. - Ростов на Дону: «Профи-Пресс», 2000. - 192 с.

Received 26.11.2020

Reviewed 19.12.2020
Revised 23.01.2021

Approved 30.03.2021

Cite as Vancouver Citation Style

Salavelis A., Pavlovsky S. Rational nutrition as a part of recovery measures for increased physical loads. Grain products and mixed fodder's, 2021; 21 (1,81): 15-20. DOI https://doi.org/

Cite as State Standard of Ukraine 8302:2015

Rational nutrition as a part of recovery measures for increased physical loads / Salavelis A. et al. // Grain Products and Mixed Fodder's. 2021. Vol. 21, Issue 1 (81). P. 15-20. DOI https://doi.org/

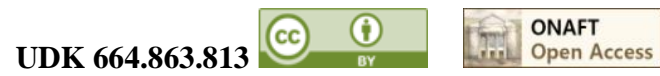

${ }^{1}$ Wang Haiyan, 2nd year master student of the Faculty of Food Technology, E.mail:2271651023@qq.com

${ }^{1}$ Melnyk Oksana, Asociate Professor, E.mail: Oksana.Melnyk@snau.edu.ua https://orcid.org/0000-0002-9201-7955, Researcher ID: V-9901-2018, Scopus 57214797466

${ }^{1}$ Sumy National Agrarian University, 180, G. Kondratiev Str., Sumy, 40021, Ukraine

${ }^{2} \mathrm{Li}$ Bo, Doctor Sciences, Professor

${ }^{2}$ Henan Institute of Science and Technology, China

\title{
FUNCTIONAL DRINK TECHNOLOGY WITH CHIA SEEDS
}

\footnotetext{
Abstract

This article mainly introduces the necessity of the emergence of functional foods and the current market development. Using chia seeds as the characteristic raw material, adding apple juice and hawthorn juice, it is developed to be suitable for subhealthy people, obese people, diabetes and cardiovascular patients.

Functional beverages refer to beverages that regulate human body functions to a certain extent by adjusting the composition and content ratio of nutrients in the beverage. In recent research hotspots, chia seeds are often developed and applied by nutritionists or other nutrition enthusiasts because of their rich nutritional value. Chia seeds are rich in a variety of unsaturated fatty acids, accounting for about $80 \%$ of the total fatty acid content, of which omega-3 and omega- 6 unsaturated fatty acids are the most content, $68 \%$ is $\alpha$-linolenic acid, which is the most abundant omega-3 fatty acid content of the food. Each $100 \mathrm{~g}$ of chia seeds contains about 16-25g of protein and about 26-40g of dietary fiber, including all 8 amino acids needed by the human body. In addition, it is also rich in vitamins and minerals, as well as a variety of natural antioxidant ingredients, with high-quality antioxidant functions. This makes the ability of chia seeds to maintain blood sugar stability, protect the heart, cerebrovascular, and promote gastrointestinal motility and bone health cannot be underestimated.

Hawthorn contains a large amount of vitamin C, carotene, organic acids and other nutrients, combined with cellulose, pectin and organic acids in apples, can further assist chia seeds to improve gastrointestinal conditions and promote gastrointestinal motility, while soluble fiber Vegetarian can regulate blood sugar.

This article chooses apple and hawthorn as flavor bases, oligosaccharides (FOS) as sweeteners, resistant starch and guar gum as composite stabilizers, to produce a chia seed functional drink to reduce weight and improve heart and brain Vascular health problems. In the extremely poor analysis of the orthogonal test results of the chia seed functional drink, the best sample formula.

Keywords: chia seeds; starch; fructose; functional food; functional drinks; weight loss; cardiovascular and cerebrovascular health.
} 


\section{Introduction}

In the 21 st century, the rapid development of science and technology, especially the advent and popularization of the Internet, accelerates the process of globalization, and the exchanges and cooperation of all walks of life between regions become more and more extensive, which greatly promotes the development and progress of each region.

Under the background that people's living standard has been greatly improved, the pace of work and life has been accelerated, and dietary habits have begun to change slowly. In order to pursue speed and efficiency, fast food culture began to prevail all over the world. In 1885, fast food originated in New York, the United States. In the following 100 years, fast food began to develop globally, which to a certain extent met the rapidly developing social needs of the world at that time, but ignored the matching of dietary nutrition [1]. In the subsequent development, with the increase of more and more discretionary wealth, people's requirements for food began to change from "eating full" to "eating well". Especially driven by industry, people's dietary structure has undergone significant changes, which are mainly reflected in:

Less and less dietary fiber in food;

More and more refined salt, oil, sugar and other food ingredients are being added.

Gradually reduce the intake of plant-based

foods;

There is an increasing number of edible foods, either semi-finished or finished.

According to the World Health Organization, an estimated 17.9 million people died from cardiovascular disease in 2016, accounting for $31 \%$ of all global deaths (2017.05.07). There are many causes of cardiovascular and cerebrovascular diseases, such as poor mental attitude, lack of exercise, staying up late, etc., which may cause cardiovascular and cerebrovascular diseases. However, the most important reason is the unreasonable diet structure and the imbalance of nutrition in the body for a long time, which leads to the failure of the body to operate normally, leading to such fatal diseases [2].

Food is one of the basic conditions for human beings to survive and multiply and maintain health. Modern studies believe that food has nutritional functions, sensory functions and physiological regulation functions, which is also an important reason why Mediterranean diet became popular [3].The Mediterranean diet is rich in omega-3, plant proteins and trace elements, etc. Existing data show that the Mediterranean diet has advantages in the prevention and treatment of cardiovascular and cerebrovascular diseases, overweight and other aspects. On the other hand, the rate of dementia in the population in this region is lower.

Certainly,with the rapid development of food industry and people's consumption level is improving, food consumption idea change constantly, people become more and more attention to the diet effects on their health level, consumption trend from the color, fragrance, taste and shape are better food with reasonable nutrition and health care function of the research and production of functional food. Its main aim is to strengthen the physical health of young people and cope with the increasing aging population and the changing attitudes towards health. Research on food functional components and development of functional food have become the focus of food research by scientists. Many countries have taken functional food research as a research topic of strategic significance to enhance international competitiveness in the new century.

At present, researches on chia seeds are mainly divided into two parts: one is to use whole chia seeds as nutritional supplements; the other is to study the nutritional value and functional application of specific nutritional components of chia seeds.

\section{Functional beverages and analysis of raw materials for their production}

\subsection{Functional foods}

There is an old saying in China, "Food is the first nature of the people", and there is a treatment method called "food therapy" in the medical field, which is the same origin of medicine and food. It is to regulate people's body, improve their physical quality and enhance their health through the way of daily diet [4]. The idea is similar to a concept Japan proposed in 1962 functional food.

The concept of functional food was first put forward by Japan [5], which refers to the food that has defensive functions, regulates the body and promotes health. After its development in Europe and the United States, local names appeared, such as "healthy food", "nutritional food", "improved food" and so on, all referring to functional food [6]. Functional foods generally have the following characteristics [7]:

(1) Contains a certain amount of bioactive substances other than known traditional nutrients;

(2) It can regulate physiological function or reduce the risk of certain diseases;

(3) Generally with food as the carrier;

(4) Take a long time to show the effect.

As an important member of food, beverage is an important source of vitamins, minerals, amino acids and other physiologically active ingredients in diet as well as thirst quenching and heat prevention with the advancement of technology [8]. In addition, because of its convenience and portability, drink beverage takes up a huge amount of advantage in modern life. Of course, good products are necessary to enter the public's attention successfully. Apart from its traditional functions, as a member of functional food, it must meet the above description of functional food.

\subsection{Analysis of raw materials for the} production of functional beverages

Among the functional drinks there are four main groups: sports; energy; healthy; nutraceuticals. This work is devoted to the development of technology for healthy drinks, which are intended for mass consumption and are the most popular functional drinks. These drinks are enriched with vitamins, minerals, unsaturated fatty acids and dietary fiber, which help prevent cardiovascular and gastrointestinal diseases, cancer and other diseases. The main components of beverages are water, often mineral, fruit and vegetable juices or mixtures thereof, milk base, stimulants. 
We suggest using apple juice as the basis of the drink and vegetable raw materials (chia seeds and hawthorn) to give the drink functional properties.

\subsubsection{Chia seeds} chia seeds.

The subject of the main new raw materials is

Chia is an annual crop, also known as Chia, Salvia hispanica L. The chia seed is its seed [9]. In South America, chia has a long history of being grown and eaten. Before Columbus discovered America, chia was the third largest food crop after corn and soybeans in Mexico and other places [10].

Chia seeds are of high nutritional value, rich in $\omega$-fatty acids, dietary fiber, protein, B vitamins, etc., as well as hydrochloric acid, thiamine, calcium, iron, manganese, phosphorus, zinc, magnesium and other minerals, which can improve the function of the body organs and prevent the accumulation of toxins in the body. Regular consumption of chia seeds can also reduce the incidence of mastitis, bowel cancer and lung cancer [11]. Chia Seeds contain a large amount of dietary fiber, has the effect that promotes intestinal health work, still can prevent obesity, stroke, heart disease, diabetes and other diseases, chia Seed gel is the study of a new type of multi-purpose edible gum, in terms of technology and the function are all in a certain research value and understand its features will greatly broaden its industrial application potential [12]. According to the American Diabetes Association (ADA), the daily recommended amount of dietary fiber is 20 to 35 grams per day. Each $100 \mathrm{~g}$ of chia seeds contains about 30 - $40 \mathrm{~g}$ of dietary fiber, which is the recommended daily amount for adults. Chia seeds contain a variety of antioxidant active substances, including chlorogenic acid and caffeic acid, followed by myricetin, quercetin, kahamnesol and tocopherol, etc. These antioxidant substances interact with each other, making the antioxidant activity of Chia seeds higher than that of single VC and VE $[13,14]$. plant seeds:

Chia seeds have other advantages over other

1. Chia seeds are rich in linolenic acid, a kind of polyunsaturated fatty acid and a precursor of omega-3 [15]. According to studies, chia seeds contain $80.5 \%$ of the total fat content of unsaturated fatty acids, and the ratio of $n-6 / n-3$ is reasonable. The imbalance between the intake of n-6 and n-3 PUFA in the human diet has been linked to cardiovascular and cerebrovascular diseases, cancer, inflammation and autoimmune diseases. Studies have shown that omega - 3 can reduce triglycerides, and chia seeds contain beta-sterols that can reduce cellular cholesterol levels [16]. Because of these good properties, it is also used in medicine.

2. The protein content of chia seeds is between $15-23 \%$, which has a great relationship with varieties and growing regions. Chia seeds have a higher protein content than traditional grains, wheat, rice, etc. It's worth noting that chia seed protein is gluten-free, so it's a great source of protein for people who are allergic to gluten. Chia seeds contain 8 kinds of essential amino acids required by human body, and the combination of amino acids is close to the ideal FAO/WHO model, and has good nutritional value [17].
3. Chia seeds are a good source of B vitamins. Compared with other cereals, the content of niacin (VB3) is higher than that of corn, soybean, oat, wheat and other traditional cereals [18].

4. Chia Seed of dietary fiber content is high, and it's surrounded by a water-insoluble dietary fiber in vitro, expansion, under the influence of water up to several times the size of the original volume, can very good increase satiety, achieve the effect that reduce weight, also because of this reason, due to the slow down the speed of digestion, makes the blood sugar and insulin can be relatively stable in a certain level [19] [20]. At present, scientists in various countries have made a series of studies on chia seed gel [21].

\subsubsection{Apple}

Apple is mainly used for seasoning and improving taste, while various organic acids contained in hawthorn can improve pepsin activity and thus promote protein digestion. Amylase can enhance the activity of pancreatic lipase and promote the digestion of fat [22]. In this project, hawthorn can assist chia seeds and improve the utilization rate of chia seeds in the body.

Apple belongs to the rosaceae deciduous trees, spherical fruit, apple is rich in VC, flavonoids, polyphenols, organic acids, soluble sugar, pectin, dietary fiber, minerals and trace elements [23], is recognized as one of the highest degree in nutrition health fruit, and low quantity of heat, every 100 grams of 52 kilocalorie of heat. The nutrients in apples are soluble and easily absorbed by the human body, so they are known as "living water" [24]. Apples are high in potassium, which combines with excess sodium and makes it go out of the body. And apple seeds are known as the "repository of life", the nutritional content is more than 10 times of the pulp. Apple seeds contain a large number of plant hormones, which can effectively regulate human endocrine, promote cell microcirculation and improve cell activity.

\subsubsection{Hawthorn}

Hawthorn is rich in a variety of nutrition and health care components, it contains protein, fat, sugar, dietary fiber, pectin, minerals and rich vitamin $\mathrm{C}$, every $100 \mathrm{~g}$ pulp contains vitamin $\mathrm{C}$ as high as $89 \mathrm{mg}$. At the same time, it is rich in calcium, with up to $85 \mathrm{mg}$ calcium per $100 \mathrm{~g}$ of flesh, which is the crown of fresh fruit [25]. Hawthorn is rich in vitamin $\mathrm{C}$, vitamin $\mathrm{B}$, carotene and a large number of organic acids and flavonoids, in which the content of carotene, organic acids and flavonoids ranks the first among fruits. Hawthorn alcohol extract has significant effects in promoting digestion, improving cardiovascular and cerebrovascular conditions, antioxidation, antibacterial and anti-virus. Hawthorn alcohol extract has a two-way regulation effect on the activity of gastric smooth muscle in stimulated rats, and has significant adjustment effect on gastrointestinal dysfunction [26]. The high methoxyl pectin (pectin for short) contained in the fruit of mountain plant is a hydrophilic colloid. Modern medical research shows that people who eat pectin for a long time have reduced cholesterol in blood, although other diets do not change a bit. Pectin can also be combined with radioactive elements in a harmless form that can be eliminated from 
the animal body and is therefore considered to have a possible anti-cancer effect [27].

\section{Relevant regulations and research methods 2.1 Relevant regulations}

Apple has always been loved by people all over the world. It can be eaten directly, can also be made into jam, juice or added to other foods. Apple is a product that must be adopted by the European Union. On January 15, 2004, the European Union announced the Apple sales standard in the "Official Gazette of the European Union" as No 85/2004.

Compared with apples, the popularity of hawthorn is not very high. Hawthorn is native to China, North Korea, and Siberia, Russia, and is currently grown in the United Kingdom, North America and other regions. The European record of the medicinal value of hawthorn first appeared in the five-volume "Medicinal Material Theory" compiled by Dios Corris. In modern clinical applications, European doctors will prescribe highly concentrated hawthorn extract to patients with heart disease. In the United States, Hawthorn tincture is one of the most widely used cardiovascular drugs [28].But compare medicinal, hawthorn is in European and American area edible or relatively less. On the website of the United States Pharmacopeia that hawthorn (Crataegus oxyacantha) fruit has been developed as one of the priority dietary supplements and is classified under the category of Botanical Ingredients [29]. In 2012, China's Health Commission identified 86 materials, including hawthorn, as both food and medicine in the Notice on Further Regulating the Management of Health Food Raw Materials.

In comparition with the above two raw materials, chia seeds are also one of the ancient foods, but they have only returned to the public eye in recent years. In 2005, Chia seeds were certified as safe food by the US Food and Drug Administration (FDA) [30].In 2009, in a talk show program, Dr.Oz, a well-known American doctor, introduced that chia seeds, a "superfood", gradually swept the world. In the same year, chia seeds were considered as a new food raw material by the European Food Safety Authority (EFSA) [31]. In 2014, according to the provisions of the Food Safety Law of the People's Republic of China and the New Food Raw Material Safety Examination and Management Measures, 6 materials including chia seeds were approved as new food raw materials in Document No. 10 of the National Health and Family Planning Commission [32].

\subsection{Research methods}

According to the material characteristics of the product and the test planning process, this article will use single factor test, orthogonal test, sensory analysis and range analysis methods to optimize the quality of the product.

\subsubsection{Single Factor Test}

Single factor test, also known as Fibonacci method, refers to a method in which other factors are fixed and only one factor is tested. Since the product designed in this article is a suspension product, it is necessary to formulate a suspension stabilizer with a suitable formula, so this method is used to screen the appropriate ratio range of a certain glue.

\subsubsection{Orthogonal Experiment}

Orthogonal experiment is also called orthogonal experiment design. It uses an orthogonal table to arrange the arrangement and combination of various experimental factors, and conduct experiments and analysis on this. The purpose is to selectively reduce the number of experiments without affecting the accuracy of the experimental results. The product designed in this article has many ingredients, so choosing this method can reduce the workload without affecting the final sample screening.

\subsubsection{Sensory Evaluation}

Sensory evaluation is a method to evaluate the appearance, smell, taste, viscosity, etc. of a sample through human taste, touch, vision, smell, etc[33]. Sensory indicators of food, such as appearance, color, taste, smell and uniformity, are often the most intuitive indicators to describe and judge product quality, it has important applications in the food field [34]. This article will use this method to score and screen experimental samples, and the sample with the highest score is the optimal sample for preliminary screening.In this experiment, 10 men and 10 women aged 22-50 years old will be selected for sensory evaluation. The specific criteria are shown in Table 1.

\subsubsection{Range Analysis}

Range analysis is one of the main analysis methods of orthogonal test results [35]. It has the advantages of intuition and convenience, and can distinguish the order of influence of various factors on the results through simple calculations. It is an important part of the optimization design step that cannot be replaced.

Table 1 Sensory score criteria

\begin{tabular}{|c|c|c|c|c|c|c|c|c|c|}
\hline Index & Disguste & Hate & Not like & $\begin{array}{l}\text { A bit of not } \\
\text { like }\end{array}$ & Normal & $\begin{array}{l}\text { A little } \\
\text { like }\end{array}$ & Like & Prefer & Adore \\
\hline Appearance & 1 & 2 & 3 & 4 & 5 & 6 & 7 & 8 & 9 \\
\hline Taste & 1 & 2 & 3 & 4 & 5 & 6 & 7 & 8 & 9 \\
\hline Smell & 1 & 2 & 3 & 4 & 5 & 6 & 7 & 8 & 9 \\
\hline Liquidity & 1 & 2 & 3 & 4 & 5 & 6 & 7 & 8 & 9 \\
\hline
\end{tabular}




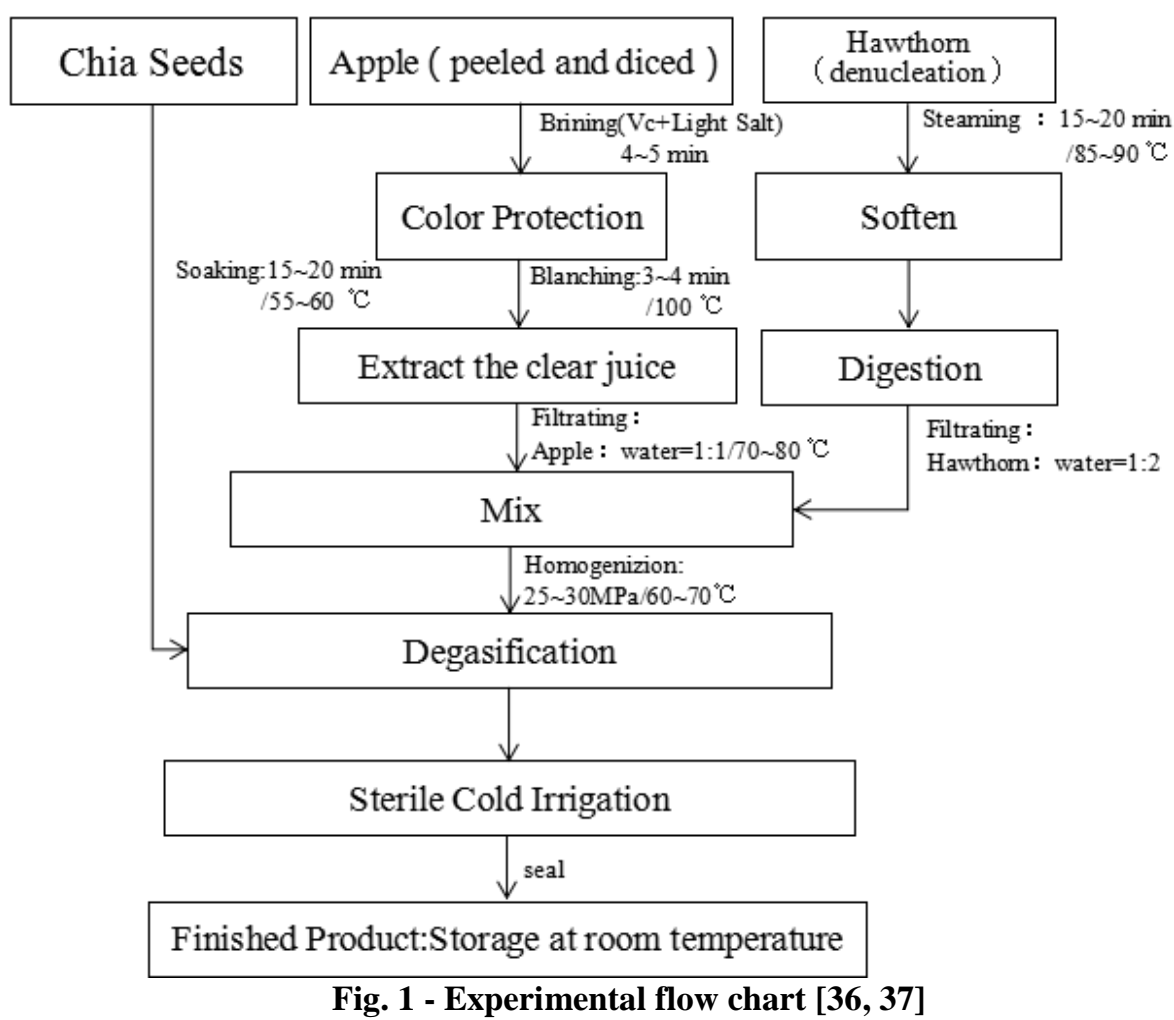

\begin{abstract}
3 Results and discussion
3.1 Development of recipe and technology of functional beverage

For these three raw materials, single factor test and orthogonal test method will be used to determine the content ratio of raw materials, and the most appropriate ratio will be selected in combination with sensory evaluation method. The specific criteria for sensory evaluation are shown in Table 1 , in which dietary fiber content shall not be less than $10 \mathrm{~g} / 100 \mathrm{~g}$. The whole experiment included: single factor test of guar gum (Table 2), rehydration test of chia seeds (Table 3), test of addition amount of flavor substances (Table 4), orthogonal test of addition amount of guar gum, resistant starch, flavor substances and mixed chia seeds (Table 5). The water used in the whole experiment is distilled water of experimental grade.
\end{abstract}

\subsection{Research of properties of raw materials} for substantiation of compounding of functional drink Single factor test

In order to improve the sensory properties of the beverage and provide the necessary rheological properties (homogeneous viscous consistency), guar gum and resistant starch will be used as the formulation components of the compound stabilizer.

Guar gum is mainly composed of galactomannan, which is relatively stable and has strong swelling and moisturizing properties. Resistant starch has good viscosity stability and rheological properties. It is insoluble in water and has the lowest water holding capacity among dietary fiber products. However, the adhesion of resistant starch is high, which can increase the opacity and suspension degree of the drink, and will not produce sand sensation, nor cover up the flavor of the drink.
Relevant experiments have proved that Yguar gum and amylose molecules can produce synergistic enhancement effects [38], while resistant starch is mainly composed of amylose, so this paper will use these two substances together with chia seed gel to form the suspension system of this product.However, since the resistant starch is insoluble in water, only single factor test of guar gum was conducted here.

Single factor test of guar gum: suspension solution was prepared by adding amount of guar gum $0.04 \%, 0.05 \%$ and $0.06 \%$ of solution mass percentage, and its suspension was observed.

Table 2 Single factor test of guar gum

\begin{tabular}{||c||l||l||}
\hline $\begin{array}{c}\text { Test } \\
\text { group }\end{array}$ & $\begin{array}{c}\text { Guar gum } \\
\text { content } \%\end{array}$ & $\begin{array}{c}\text { Suspension property } \\
(30 \mathrm{~d})\end{array}$ \\
\hline \hline $\mathbf{1}$ & 0.04 & Part of the suspended \\
\hline \hline $\mathbf{2}$ & 0.05 & Basic suspended \\
\hline \hline $\mathbf{3}$ & 0.06 & Major sedimented \\
\hline
\end{tabular}

Note: The guar gel should be kept in a sealed, oxygen-free and sterileenvironment during the experimental observation.

\section{Orthogonal test}

Chia Reed Rehydration

After rehydration, the surface of chia seeds will absorb water to form a transparent viscous liquid, namely, chia seed gel. Chia seed gel itself has the physical and chemical properties of general gels, which can bind chia seeds to make them suspended. The optimal rehydration conditions for the suspension of chia seeds were analyzed by adjusting time, temperature and the ratio of chia seeds to water. The orthogonal test results were shown in Table 3: 
Table 3 Chia seed rehydration test results

\begin{tabular}{||c||c||c||c||c||}
\hline $\begin{array}{c}\text { Test } \\
\text { Group }\end{array}$ & $\begin{array}{c}\text { Time } \\
(\mathrm{min})\end{array}$ & $\begin{array}{c}\text { Tempe- } \\
\text { rature } \\
\left({ }^{\circ} \mathrm{C}\right)\end{array}$ & $\begin{array}{c}\text { Chia } \\
\text { seeds: } \\
\text { Water }\end{array}$ & $\begin{array}{c}\text { Suspension } \\
\text { property (30d) }\end{array}$ \\
\hline \hline $\mathbf{1}$ & 10 & 50 & $1: 20$ & $\begin{array}{c}\text { Part of the } \\
\text { suspension }\end{array}$ \\
\hline \hline $\mathbf{2}$ & 10 & 55 & $1: 25$ & Major suspension \\
\hline \hline $\mathbf{3}$ & 10 & 60 & $1: 30$ & Partial suspension \\
\hline \hline $\mathbf{4}$ & 15 & 50 & $1: 25$ & $\begin{array}{c}\text { Part of the } \\
\text { suspension }\end{array}$ \\
\hline \hline $\mathbf{5}$ & 15 & 55 & $1: 30$ & All suspended \\
\hline \hline $\mathbf{6}$ & 15 & 60 & $1: 20$ & Partial suspension \\
\hline \hline $\mathbf{7}$ & 20 & 50 & $1: 30$ & Major suspension \\
\hline \hline $\mathbf{8}$ & 20 & 55 & $1: 20$ & Major suspension \\
\hline \hline $\mathbf{9}$ & 20 & 60 & $1: 25$ & All precipitation \\
\hline \hline
\end{tabular}

Note: During the experimental observation, the mixture of chia seeds and water should be kept in a sealed, oxygen-free and sterile environment.

\section{Flavor substance addition amount}

In this study, apple and hawthorn were used as flavor substances, and fructose oligosaccharides(FOS) and citric acid were used as flavoring agents. According to the quality ratio (apple juice : Hawthorn juice) was 1 : $1,1: 2,2: 3$, original juice content was $30 \%, 40 \%$, $50 \%$, fructose oligosaccharide (FOS) added amount was $2 \%, 3 \%, 4 \%$, citric acid added amount was $0.02 \%$, $0.04 \%, 0.06 \%$, using $\mathrm{L}_{9}\left(3^{4}\right)$ orthogonal table for the test, the test results are shown in Table 4:

The experimental results showed that when apple juice and hawthorn juice were $2: 3$ and original juice content was $50 \%$, the sensory quality of the product was the best. At this time, the content of apple juice was equivalent, and the aroma was rich. Moreover, adding $3 \%$ fructose oligo to counteract the taste of hawthorn and citric acid and not to cover up the taste, the sour and sweet had the effect of promoting appetite.
Compound stabilizer, flavor substance and chia seed addition amount

After rehydration of chia seeds, its itself is suspended, but the suspension effect is limited by temperature, time and amount of seed, beyond a certain limit, can expand excessively, seed gel eventually fall off, so in order to ensure product shelves effect and taste flavor, you need to add a dose of stabilizers, flavor substances and sweeteners, specific results as shown in table 5:

\section{Test Result}

According to the analysis of the test results, 3 / 5 / 7 the three groups of test samples all achieved the effect of suspension, but when the flavor substance was $70 \%$, the addition amount of chia seed was $3 \%$, the compound stabilizer was $0.05 \%$ guar gum, and $0.06 \%$ resistant starch, the sensory score of the samples was the highest. At this time, the product had good fluidity, the proportion of chia seeds was appropriate, and the proportion of mixed fruit juice was the highest.

\subsection{Orthogonal Test - Range Analysis of sensory} evaluation results

It can be seen from Table 5 that the test results of sample 5 are the most ideal. In this experiment, the addition of guar gum, resistant starch, flavor substances, and chia seeds are used as fixed factors, and sensory scores alone are not sufficient to be the final best index, so other data analysis methods are needed to achieve the purpose of process optimization. Compared with variance analysis, range analysis is more intuitive and can complete the experimental requirements more quickly.

The orthogonal test table in Table 5 is $\mathrm{L}_{9}\left(3^{4}\right)$, then the factor level $\mathrm{m}=3$, the number of orthogonal table columns $\mathrm{k}=4$, the total number of tests $\mathrm{n}=9$. Table 5 can be transformed into Table 6 , where A, B , C, $\mathrm{D}$ represent the added amount of guar gum, resistant starch, flavor substances and chia seeds, respectively. The test result $\mathrm{Yi}$ is the corresponding sensory evaluation result.Among them, $\mathrm{K}_{\mathrm{mi}}$ is the sum of the test results (sensory scores) of the factor $\mathrm{m}$ in the $\mathrm{i}$-th column, $\mathrm{K}$ is the sum of the test results (sensory scores) of the 9 test groups, $\hat{\mathrm{Y}}_{\mathrm{mi}}$ is the average of the m-level test results of the $\mathrm{i}$ - th factor, $R_{j}$ is the range of the factor in the $\mathrm{j}-$ th

Table 4 Test results of flavor substance addition amount (result evaluation criteria refer to Table 1)

\begin{tabular}{|c|c|c|c|c|c|}
\hline $\begin{array}{c}\text { Test } \\
\text { Group }\end{array}$ & $\begin{array}{l}\text { Apple juice: Hawthorn } \\
\text { juice }\end{array}$ & $\begin{array}{c}\text { Original juice } \\
\text { content } \%\end{array}$ & FOS \% & Citric acid \% & $\begin{array}{l}\text { The sensory } \\
\text { score }\end{array}$ \\
\hline 1 & $1: 1$ & 30 & 2 & 0.02 & 7.8 \\
\hline 2 & $1: 1$ & 40 & 3 & 0.04 & 7.9 \\
\hline 3 & $1: 1$ & 50 & 4 & 0.06 & 7.4 \\
\hline 4 & $1: 2$ & 30 & 3 & 0.06 & 6.9 \\
\hline 5 & $1: 2$ & 40 & 4 & 0.02 & 8.1 \\
\hline 6 & $1: 2$ & 50 & 2 & 0.04 & 6.8 \\
\hline 7 & $2: 3$ & 30 & 4 & 0.04 & 7.7 \\
\hline 8 & $2: 3$ & 40 & 2 & 0.06 & 7.3 \\
\hline 9 & $2: 3$ & 50 & 3 & 0.02 & 8.7 \\
\hline
\end{tabular}


Table 5 Test results of the addition amount of guar gum (GG), resistant starch (RS), flavor substance (FS) and chia seed(CS)

\begin{tabular}{||c||c||c||c||c||c||c||}
\hline $\begin{array}{c}\text { Test } \\
\text { Group }\end{array}$ & GG \% & RS \% & FS \% & CS \% & Suspension Property (30d) & $\begin{array}{c}\text { Sensory } \\
\text { Score }\end{array}$ \\
\hline \hline $\mathbf{1}$ & 0.045 & 0.04 & 50 & 3 & Part of the suspended & 7.3 \\
\hline \hline $\mathbf{2}$ & 0.045 & 0.06 & 60 & 4 & Part of the suspended & 7.7 \\
\hline \hline $\mathbf{3}$ & 0.045 & 0.08 & 70 & 5 & Major suspended & 8 \\
\hline \hline $\mathbf{4}$ & 0.05 & 0.04 & 60 & 5 & Part of the suspended & 7 \\
\hline \hline $\mathbf{5}$ & 0.05 & 0.06 & 70 & 3 & All suspended & 8.4 \\
\hline \hline $\mathbf{6}$ & 0.05 & 0.08 & 50 & 4 & All suspended & 7.1 \\
\hline \hline $\mathbf{7}$ & 0.055 & 0.04 & 70 & 4 & Major suspended & 8.2 \\
\hline \hline $\mathbf{8}$ & 0.055 & 0.06 & 50 & 5 & Part of the suspended & 6.5 \\
\hline $\mathbf{9}$ & 0.055 & 0.08 & 60 & 3 & All suspended & 7.6 \\
\hline
\end{tabular}

column, that is, the difference between the maximum and the minimum of the average index value at each level of the factor in the jth column. The specific calculation process is as follows:

$$
\begin{aligned}
& \mathrm{K}_{1}\left\{\begin{array}{l}
\mathrm{K}_{11}=7.3+7.7+8=23 \\
\mathrm{~K}_{12}=7.3+7+8.2=22.5 \\
\mathrm{~K}_{13}=7.3+7.1+6.5=20.9 \\
\mathrm{~K}_{14}=7.3+8.4+7.6=23.3
\end{array}\right. \\
& \mathrm{K}_{2}\left\{\begin{array}{l}
\mathrm{K}_{21}=7+8.4+7.1=22.5 \\
\mathrm{~K}_{22}=7.7+8.4+6.5=22.6 \\
\mathrm{~K}_{23}=7.7+7+7.6=22.3 \\
\mathrm{~K}_{24}=7.7+7.1+8.2=23 \\
\mathrm{~K}_{31}=8.2+6.5+7.6=22.3 \\
\mathrm{~K}_{32}=8+7.1+7.6=22.7 \\
\mathrm{~K}_{33}=8+8.4+8.2=24.6 \\
\mathrm{~K}_{34}=8+7+6.5=21.5
\end{array}\right.
\end{aligned}
$$

$\hat{\mathrm{Y}}_{\mathrm{mi}}=\frac{\operatorname{Kim}}{m},(0<\mathrm{m}<4, \mathrm{~m}$ is an integer $)$

$\mathrm{R}_{\mathrm{j}}=\max \left(\hat{\mathrm{Y}}_{\mathrm{mi}}\right)-\min \left(\hat{\mathrm{Y}}_{\mathrm{mi}}\right)$

The specific results are shown in Table 6 .

The optimal level of factor $\mathrm{j}$ and the level combination of each factor can be judged by the size of $\mathrm{K}_{\mathrm{j}}$, that is, the optimal combination. The optimal level of each column of factors is $\operatorname{Max}\left(\mathrm{K}_{\mathrm{j}}\right)$. $\mathrm{R}_{\mathrm{j}}$ reflects the change range of the corresponding test index when the level of the $\mathrm{j}$-th factor changes. The larger the $\mathrm{R}_{\mathrm{j}}$, the greater the influence of this factor on the test index, and therefore the more important it is.From the calculation results in
Table 6, it can be seen that the optimal combination of the orthogonal experiment should be $\mathrm{A}_{1} \mathrm{~B}_{3} \mathrm{C}_{3} \mathrm{D}_{1}$, and the primary and secondary order of each factor should be $\mathrm{C}>$ D> A> B. Returning to Table 5, it can be seen from the results of the orthogonal experiment that the combination with the highest sensory score is $\mathrm{A}_{2} \mathrm{~B}_{2} \mathrm{C}_{3} \mathrm{D}_{1}$, while the optimal combination obtained by the range analysis does not appear in the orthogonal table. The difference between the two groups is mainly due to the two secondary factors $\mathrm{C}$ and $\mathrm{D}$, that is, the amount of guar gum and resistant starch added.

Resistant starch (RS) is a new type of dietary fiber, which refers to starch and its degradation products that cannot be absorbed by the small intestine of healthy humans. It can effectively solve the defects of ordinary dietary fiber [39]. $\mathrm{RS}_{3}$ resistant starch was used in this paper, which is the most studied resistant starch at present. A large number of studies have shown that RS is difficult to convert into easily absorbed glucose in the body, so it has a regulatory effect on glucose and insulin levels in the body [40], has a certain effect on weight control and intestinal management, and has prebiotics Efficacy is one of the research hotspots in the field of nutrition, which overlaps with the design function of this product, which means that resistant starch is not only used as a thickener in this product, but also a functional ingredient.

Therefore, under the condition of not affecting the product quality, the priority order of each factor and the product characteristics are integrated, and $\mathrm{A}_{1} \mathrm{~B}_{3} \mathrm{C}_{3} \mathrm{D}_{1}$ is finally selected as the best formula combination of this product.

\subsection{The nutritional value of the finished product}

After determining the composition ratio, the nutritional value of the product can be measured, which provides a certain reference for subsequent mass production and consumption.

Each $100 \mathrm{ml}$ of this product also contains $0.69 \mathrm{~g}$ of retinol, which is one of the 13 essential vitamins for the human body. It is a fat-soluble antioxidant that maintains vision, promotes bone growth, inhibits tumors, and improves immunity [41]. 
Table 6 Range analysis results

\begin{tabular}{|c|c|c|c|c|c|}
\hline Test Group & A & $\mathrm{B}$ & $\mathrm{C}$ & $\mathrm{D}$ & Test Results(Yi) \\
\hline 1 & 1 & 1 & 1 & 1 & 7.3 \\
\hline 2 & 1 & 2 & 2 & 2 & 7.7 \\
\hline 3 & 1 & 3 & 3 & 3 & 8 \\
\hline 4 & 2 & 1 & 2 & 3 & 7 \\
\hline 5 & 2 & 2 & 3 & 1 & 8.4 \\
\hline 6 & 2 & 3 & 1 & 2 & 7.1 \\
\hline 7 & 3 & 1 & 3 & 2 & 8.2 \\
\hline 8 & 3 & 2 & 1 & 3 & 6.5 \\
\hline 9 & 3 & 3 & 2 & 1 & 7.6 \\
\hline $\mathbf{K}_{1}$ & 23 & 22.5 & 20.9 & 23.3 & $67.8(\mathrm{~K})$ \\
\hline $\mathbf{K}_{2}$ & 22.5 & 22.6 & 22.3 & 23 & \\
\hline $\mathbf{K}_{\mathbf{3}}$ & 22.3 & 22.7 & 24.6 & 21.5 & \\
\hline Excellent level & $\mathrm{A} 1$ & B3 & $\mathrm{C} 3$ & D1 & \\
\hline$\hat{\mathbf{Y}}_{1}$ & 7.67 & 7.50 & 6.97 & 7.77 & \\
\hline$\hat{\mathbf{Y}}_{2}$ & 7.50 & 7.53 & 7.43 & 7.67 & \\
\hline$\hat{\mathbf{Y}}_{3}$ & 7.43 & 7.57 & 8.20 & 7.17 & \\
\hline $\mathbf{R}$ & 0.23 & 0.07 & 1.23 & 0.60 & \\
\hline Primary and secondary order & \multicolumn{5}{|c|}{$\mathrm{C}>\mathrm{D}>\mathrm{A}>\mathrm{B}$} \\
\hline
\end{tabular}

Table 7 The nutritional value of the finished product

\begin{tabular}{|c|c|}
\hline Nutritions / Materials & Total \\
\hline Calories(kcal) & 38.78 \\
\hline Fat $(g)$ & 1.05 \\
\hline Saturated Fatty Acids(g) & 0.10 \\
\hline Total Carbohydrate $(\mathrm{g})$ & 6.96 \\
\hline Dietary Fiber(g) & 4.53 \\
\hline Sugar $(g)$ & 1.70 \\
\hline $\operatorname{Pectin}(\mathrm{g})$ & 1.64 \\
\hline $\operatorname{Protein}(g)$ & 0.60 \\
\hline Vitamin c(mg) & 16.34 \\
\hline Calcium(mg) & 22.53 \\
\hline Copper(mg) & 0.15 \\
\hline $\operatorname{Iron}(\mathrm{mg})$ & 0.38 \\
\hline Magnesium(mg) & 12.25 \\
\hline Phosphorus(mg) & 29.40 \\
\hline Potassium(mg) & 43.56 \\
\hline Sodium(mg) & 0.95 \\
\hline Zinc(mg) & 0.27 \\
\hline Selenium $(\mathrm{mcg})$ & 1.88 \\
\hline
\end{tabular}

In this product, the calorie of the product is only $38.78 \mathrm{kcal}$, the fat content is $1.05 \mathrm{~g}$ (about $90 \%$ unsaturated fatty acid), the protein content is $0.6 \mathrm{~g}$ per $100 \mathrm{ml}$, the carbohydrate is $65 \%$ dietary fiber $(4.53 \mathrm{~g} /$ $100 \mathrm{ml}$ ), and only fructose oligosaccharides is used as sweetener. These have relatively small and slow effects on the rise and fall of blood Sugar and lipid levels. Although apples and hawthorn also contain certain Sugar, the amount is very small, with only $1.7 \mathrm{~g}$ per 100 $\mathrm{ml}$.

Therefore, this product is very suitable for people who want to lose weight, improve constipation and intestinal flora, or prevent and improve cardiovascular and cerebrovascular diseases to drink. Moreover, due to its low calorie and low sugar content, it can also be consumed by diabetic people.

However, it is not recommended for pregnant women, people with dysentery or those who have undergone gastrointestinal surgery for its high dietary fiber content.

\section{Conclusion}

Chia seed has become one of the research hotspots in the field of food nutrition because of its rich nutrition, high edible value and various health-promoting effects. More and more countries begin to pay attention to the search and utilization of new healthy raw materials. With the continuous extension and deepening of global communication, more and more traditional foods begin to find more efficient ways to use them.

Chia seeds can be used as a good source of omega-3 fatty acids, gluten-free protein, dietary fiber and 
other nutrients needed by the human body, but inappropriate amount of consumption will cause the burden of the stomach, and hawthorn contains a large number of organic acids, enzymes, flavonoids and other substances can effectively promote the digestion and absorption of intestinal fat and protein. This topic is to combine two kinds of high-nutrient raw materials from different regions to achieve the synergy of ' $1+1>2$ ', and provide a kind of health functional drinks without burden for people threatened by cardiovascular and cerebrovascular problems, obesity, cancer, etc.
At present, there are relatively few studies on chia seed drinks, and most of them are directly added with chia seeds as whole seeds. However, there is no conclusion on how many nutrients such chia seeds will be absorbed by the human body after entering the stomach and intestines.

In this paper, the combination of chia seeds and hawthorn is to improve the absorption efficiency of chia seeds in human body with the help of a large number of organic acids contained in hawthorn, but the specific data need to be further verified through clinical trials.

\section{REFERENCES:}

1. Song H Y, Guo Y L. Analysis on cultural differentiation of Chinese and American fast food [J]. Food Safety Guide,2020(36):1819.

2. Jiang T X. What are the risk factors of cardiovascular disease [J]. Family Life Guide: Next 10 (1):0187-0187.

3. Medina F X. Towards a Construction of the Mediterranean Diet? The Building of a Concept between Health, Sustainability and Culture[J]. Food ethics,2021,6(1):2364-6861. https://doi.org/10.1007/s41055-020-00083-4.

4. Liu C X. Understanding " medicine and food homology ",developing utilization in medicine functions[J]. Chinese Herbal Medicines, 2018,10 (04):337-338.

5. Jin Z L. Principles and methods of functional food evaluation. Beijing: Peking University Press, 1995.

6. Mathias D. Staying Healthy From 1 to 100[M]. Berlin, Heidelberg: Springer,2016.

7. Zheng JX(Ed.). Functional food science [M]. Beijing: China light industry press, 2003.

8. Li X M, Fang Y C, Zhao J F. Research progress and application foreground of energy drinks [J]. China Food Additives, 1999( 4): $19-22$.

9. Ning WW. Extraction and functional properties of protein from Chia (Salvia hispanica L.) seed[D].Shanghai:Shanghahi Ocean University, 2017.

10. Muñoz L A. ChiaSeed(Salviahispanica) : an ancient grain and a new functional food[J]. Food Reviews International, 2013, 29(4) : 394-408.

11. de Falco B, Amato M \& Lanzotti V. Chia seeds products: an overview[J]. Phytochemistry Reviews, 2017,16(4):745-760.

12. Rong X, Tao N P, Li Y Q, et al. Nutrition analysis and evaluation of chia seeds [J]. China Oils and Fats, 2015, 40(9): 89-93.

13. Muñoz L A, Aguilera J M, Rodriguez-Turienzo L,et al. Characterization and microstructure of films made from mucilage of Salvia hispanica and whey protein concentrate. Journal of Food Engineering, 2012, 111(3):511-518.

14. Reyes-Caudillo E, Tecante A, Valdivia-López M A. Dietary fibre content and antioxidant activity of phenolic compounds present in Mexican chia (Salvia hispanicaL.) seeds. Food Chemistry, 2008, 107(2):656-663.

15. Jin Q Z (Editor-in-chief ). Functional lipids[M]. Beijing: China Light Industry Press, 2013.08.

16. Vuksan V, Jenkins A L, Dias A $G$, et al. Reduction in postprandial glucose excursion and prolongation of satiety: possible explanation of the long-term effects of whole grain Salba (Salvia Hispanica L.). European Journal of Clinical Nutrition, 2010, 64(4):436-8.

17. Wen $N$, Ning $W W$, Tao $N$ P. Extraction and nutritional evaluation of chia seed protein[J]. China Oils and Fats, 2018,43(09):44-48.

18. Bushway A A,Belyea P R,Bushway R J. Chia Seed as a Source of Oil, Polysaccharide, and Protein[J]. Journal of Food Science, 1981, 46(5):1349-1350.

19. Vuksan V, Whitham D, Sievenpiper J L, Jenkins A L,et al. Supplementation of conventional therapy with the novel grain Salba (Salvia hispanica L.) improves major and emerging cardiovascular risk factors in type 2 diabetes: results of a randomized controlled trial. Diabetes Care, 2007, 30(11):2804-2810.

20. Strand E, Pedersen E R, Svingen GF, Schartum-Hansen H, et al. Dietary intake of n-3 long-chain polyunsaturated fatty acids and risk of myocardial infarction in coronary artery disease patients with or without diabetes mellitus: a prospective cohort study. Bmc Medicine, 2013, 11(14):1506-1507.

21. Julio L M, Ixtaina V Y, Fernández M, et al. Development and characterization of functional O/W emulsions with chia seed (Salvia hispanica L.) by-products[J]. Journal of Food Science and Technology,2016,53(8):3206-3214. https://doi.org/10.1007/s13197-016-2295-8.

22. Shi $G Y, W u W H$, Shang $Q J$, et al. Research progress on pharmacological effects and health care application of hawthorn for medicine and food[J]. Modern Food,2020(15):126-128.

23. Wang J, Li H Y, Liu D L, et al. Research progress on the nutritional components and health effects of apples[J].Food Research and Development,2011,32(1):164-169.

24. Li L. Apple and health [J]. Family Medicine: Medical Selection,2020(2):83-83.

25. Lu D F. Nutritional value and utilization of hawthorn [J]. Agricultural Products Processing,2012(08):30-31.

26. Liang Z, et al. Practical medical diet guide [M]. Wuhan: Hubei Science and Technology Press, 1983:612-615.

27. Zhao Y, Shi $Q$ L, Zhu J Y. Nutritional value and processing technology of hawthorn[J]. Cereals and Oils Processing and Food Machinery,2003(10):84-85.

28. Vaughn B. Hawthorn: The Tree That Has Nourished, Healed, and Inspired Through the Ages[M]. Yale University Press, 2015.

29. USP. Dietary Supplements list of monographs prioritized for development[Z]. https://www.usp.org/dietary-supplementsherbal-medicines/development-process/monograph-lists.

30. Hao Y, Xu Z X, Liu C P, et al. Chinese Journal of Oils and Fats, 2018 (7): 28.

31. THE CHIA COMPANY. Request for scientific evaluation of substantial equivalence application for the approval of chia seeds (Salvia Hispanica L. ) from The Chia Company for use in bread[S]. Food Standards Agency: London, UK, 2009. 
32. National Health and Family Planning Commission of the People's Republic of China. Announcement on the approval of 6 new food raw materials such as Tag sugar [S]. Department of Food Safety Standards and Health Assessment, 2014(6).

33. Wang J J.The preparation process of apple and hawthorn compound beverage[J].Agriculture and Technology,2016,36(09):4850 .

34. Reheman A, Yang H, Ma M S, Wang Y T, Aierken G. Application of Orthogonal Design in Formula Technology of Apple Juice Drinks[J]. Modern Food,2019(16):82-85+93.

35. 38.Tang J L,Xu Z T. Analysis of Range and Analysis of Variance in Orthogonal Experiments[J].Middle School Mathematics, 2017(9):31-34.

36. Morten M, Gail V C, Thomas C M. Sensory Evaluation Techniques[M]. Boca Raton:CRC Press, 2006.

37. Wang $N$, Jiang $J Q$, Chen $H Y$. The function and method of food sensory evaluation [J]. Agricultural Science and Technology and Equipment,2020(06):63-64.

38. Wu $Y Q$, Tang M M, Hong Y, Gu Z B. Effect of amylose content on gelatinization and rheological properties of corn starch/guar gum composite system [J].Journal of Food and Biotechnology,2014,33(01):48-55.

39. Ни Z Z, Hao Z S, Meng Y, et al. Research progress on the preparation, efficacy and application of resistant starch[J]. Chinese Food and Nutrition,2021,27(01):30-35.

40. Zhou Z K, Wang F, Ren X C, et al.Resistant starch manipulated hyperglycemia / hyperlipidemia and related genes expression in diabetic rats[J].International Journal Biological Macro Molecules,2015(75):316 - 321.

41. Khillan J S. Vitamin A/ retinol and maintenance of pluripotency of stem cells[J]. Nutrients,2014,6(3):1209-1222. DOI:10.3390/nu6031209.

${ }^{\mathbf{1}}$ Ванг Хайян, студентка 2 курсу факультеу харчових технологій, E.mail: 2271651023@qq.com

${ }^{1}$ Мельник Оксана, канд. наук, доцент, E.mail: Oksana.Melnyk@snau.edu.ua https://orcid.org/0000-0002-9201-7955, Researcher ID: V-9901-2018, Scopus 57214797466 ${ }^{1}$ Сумський національний аграрний університет, вул. Г. Кондратьєва 160, Суми, 40021, Украна

${ }^{2}$ Лі Бо, д-р наук, професор,

${ }^{2}$ Хенаньский Інститут науки і технологій, Хенань, Китай

\section{ФУНКЦІОНАЛЬНА ТЕХНОЛОГІЯ НАПОЇВ 3 НАСІННЯМ ЧІА}

\section{Анотація}

В статті висвітлено тема розроблення функціональних продуктів харчування, зокрема напоїв. Використання насіння чіа, як сировини, що має високу харчову цінність, внесення яблучного соку та соку глоду, дозволить отримати продукт, який зможуть споживати люди, які страждають ожирінням, цукровим діабетом та серцево-судинними захворюваннями.

Функціональні напої впливають на функції організму. Огляд наукових досліджень свідчить, що насіння чіа часто застосовується дієтологами, як сировина, яка має підвищену харчову цінність. Насіння чіа багате різноманітними ненасиченими жирними кислотами, на них припадає близько 80\% загального вмісту жирних кислот, 3 яких міститься найбільше омега-3 та омега-6 жирних кислот, 68\% - це $\alpha$-ліноленова кислота. Кожні 100 г насіння чіа містять близько 16-25 г білка і близько 26-40 г харчових волокон, включаючи всі 8 амінокислот, необхідних організму людини. Крім того, насіння чіа також багате вітамінами та мінералами, а також різноманітними природними антиоксидантними інгредієнтами з високими антиоксидантними властивостями. Внесення у напої насіння чіа дозволяє підтримувати стабільність цукру в крові, захищати серце, цереброваскулярні судини, а також покращує перистальтику шлунково-кишкового тракту і поліпшує міцність кісток.

Глід містить велику кількість вітаміну С, каротину, органічних кислот та інших поживних речовин у поєднанні з целюлозою, пектином та органічними кислотами в яблуках та в поєднанні з насінням чіа сприяє покращенню стану шлунково-кишкового тракту та покращує моторику шлунково-кишкового тракту, а вміст розчинної клітковина впливає на регуляцію рівню цукру в крові.

В даній роботі було вибрано яблуко та глід, як ароматичні основи, олігосахариди (FOS), як підсолоджувачі, резистентний крохмаль та гуарову камедь, як композиційні стабілізатори для виробництва функціонального напою з насіння чіа, вживання якого сприяє зниженню ваги та профілактиці серцево-судинних захворювань. За допомогою ортогонального аналізу результатів випробувань було отримано співвідношення основних компонентів функціонального напою.

Ключові слова: насіння чіа; крохмаль; фруктоза; функціональне харчування; функціональні напої; втрата ваги; серцево-судинне та цереброваскулярне здоров'я.

\section{ЛIТЕРАТУРА}

1. 宋华烨, 郭雅伦. 中美快餐文化差异化分析[J]. 食品安全导刊,2020(36):18-19.

2. 蒋天祥.引起心血管疾病的诱因有哪些[J].家庭生活指南: 下旬刊,2020(1):0187-0187

3. Medina F X. Towards a Construction of the Mediterranean Diet? The Building of a Concept between Health, Sustainability and Culture[J]. Food ethics,2021,6(1):2364-6861. https://doi.org/10.1007/s41055-020-00083-4.

4. Liu C. Understanding "medicine and food homology",developing utilization in medicine functions[J]. Chinese Herbal Medicines, 2018, 10(04):5-6.

5. 金宗濂. 功能食品评价原理与方法. 北京: 北京大学出版社, 1995.

6. Mathias D. Staying Healthy From 1 to 100[M]. Berlin, Heidelberg: Springer,2016. 
7. 郑建仙(编).功能性食品学 $[M]$ 。北京: 中国轻工业出版社, 2003。.

8. 李小满, 方元超, 赵晋府. 功能性饮料研究进展与应用前景[J]. 中国食品添加剂, 1999(4):19-22.

9. 宁伟伟. 奇亚籽蛋白的提取及其功能特性研究[D].上海海洋大学,2017.

10. Muñoz L A. ChiaSeed(Salviahispanica) : an ancient grain and a new functional food[J]. Food Reviews International, 2013, 29(4) : 394-408.

11. de Falco B, Amato M \& Lanzotti V. Chia seeds products: an overview[J]. Phytochemistry Reviews, 2017,16(4):745 - 760.

12. 荣旭, 陶宁萍, 李玉琪, 等. 奇亚籽营养成分分析与评价[J]. 中国油脂, 2015, 40(9): 89-93.

13. Muñoz L A, Aguilera J M, Rodriguez-Turienzo L,et al. Characterization and microstructure of films made from mucilage of Salvia hispanica and whey protein concentrate. Journal of Food Engineering, 2012, 111(3):511-518.

14. Reyes-Caudillo E, Tecante A, Valdivia-López M A. Dietary fibre content and antioxidant activity of phenolic compounds present in Mexican chia (Salvia hispanicaL.) seeds. Food Chemistry, 2008, 107(2):656-663.

15. 金青哲主编. 功能性脂质 $[M]$. 北京：中国轻工业出版社, 2013.08

16. Vuksan V, Jenkins A L, Dias A $G$, et al. Reduction in postprandial glucose excursion and prolongation of satiety: possible explanation of the long-term effects of whole grain Salba (Salvia Hispanica L.). European Journal of Clinical Nutrition, 2010, 64(4):436-8.

17. 文宁, 宁伟伟, 陶宁萍.奇亚籽蛋白的提取和营养评价[J]. 中国油脂,2018,43(09):44-48.

18. Bushway A A,Belyea P R,Bushway R J. Chia Seed as a Source of Oil, Polysaccharide, and Protein[J]. Journal of Food Science, 1981, 46(5):1349-1350.

19. Vuksan V, Whitham D, Sievenpiper J L, Jenkins A L,et al. Supplementation of conventional therapy with the novel grain Salba (Salvia hispanica L.) improves major and emerging cardiovascular risk factors in type 2 diabetes: results of a randomized controlled trial. Diabetes Care, 2007, 30(11):2804-2810.

20. Strand E, Pedersen E R, Svingen G F, Schartum-Hansen H, et al. Dietary intake of n-3 long-chain polyunsaturated fatty acids and risk of myocardial infarction in coronary artery disease patients with or without diabetes mellitus: a prospective cohort study. Bmc Medicine, 2013, 11(14):1506-1507.

21. Julio L M, Ixtaina VY, Fernández M, et al. Development and characterization of functional O/W emulsions with chia seed (Salvia hispanica L.) by-products[J]. Journal of Food Science and Technology,2016,53(8):3206 -3214. https://doi.org/10.1007/s13197-016-2295-8.

22. 史国玉, 武卫红, 商庆节, 赵永矅, 姜斌, 李群芳. 药食两用山楂的药理作用及保健应用研究进展 $[J]$. 现代食品, 2020(15):126128.

23. 王胶, 李赫宇, 刘岱琳, 等. 苹果的营养成分及保健功效研究进展[J]. 食品研究与开发,2011,32(1):164-169.

24. 李丽. 苹果与健康 $[J]$. 家庭医药: 就医选药,2020(2):83-83.

25. 卢东飞. 山楂的营养价值及其利用[J].农产品加工,2012(08):30-31

26. 梁志编.实用医疗饮食指南 $[M]$. 武汉: 湖北科学技术出版社.1983：612-615

27. 赵亚, 石启龙, 朱继英. 山楂的营养价值及加工技术 $[J]$. 粮油加工与食品机械, 2003(10):84-85.

28. Vaughn B. Hawthorn: The Tree That Has Nourished, Healed, and Inspired Through the Ages[M]. Yale University Press, 2015.

29. USP. Dietary Supplements list of monographs prioritized for development[Z]. https://www.usp.org/dietary-supplements-herbalmedicines/development-process/monograph-lists.

30. 岳昊, 徐志祥, 刘翠平, 等. 奇亚籽油的健康功效[J]. 中国油脂, 2018 (7): 28.

31. THE CHIA COMPANY. Request for scientific evaluation of substantial equivalence application for the approval of chia seeds (Salvia Hispanica L. ) from The Chia Company for use in bread[S]. Food Standards Agency: London, UK, 2009.

32. 中华人民共和国国家卫生和计划生育委员会. 关于批准塔格糖等 6 种新食品原料的公告 $[S]$. 食品安全标准与健康评估司, 2014( 6).

33. 王姣姣.苹果山楂复合饮料制备工艺 $[J]$. 农业与技术,2016,36(09):48-50.

34. 阿依帕夏 - 热合曼, 杨行, 马铭赛, 王玉涛, 古丽米热 - 艾尔肯. 正交设计在苹果汁饮料配方工艺中的应用 $[\mathrm{J}]$. 现代食品, 2019( 16):82-85+93.

35. 唐佳丽, 徐章蹈.正交试验中的极差分析与方差分析 $[J]$. 中学数学,2017(9):31-34.

36. Morten M, Gail V C, Thomas C M. Sensory Evaluation Techniques[M]. Boca Raton:CRC Press, 2006.

37. 王宁, 姜金岐, 陈鹤月. 食品感官评价的作用及与方法概述 $[J]$. 农业科技与装备,2020(06):63-64.

38. 吴银琴, 唐敏敏, 洪雁, 顾正彪. 直链淀粉含量对玉米淀粉 $/$ 爪尔胶复配体系糊化和流变特性的影响 $[J]$. 食品与生物技术学报, 2014,33(01):48-55.

39. 胡珍珍, 郝宗山, 孟妍,王倩, 徐红照, 位雅莉, 陈立勇. 抗性淀粉的制备、功效及应用的研究进展 $[J]$. 中国食物与营养,2021,27( 01):30-35.

40. ZhongKai Zhou, Fang Wang, XiaoChong Ren, Yuyang Wang, Chris Blanchard. Resistant starch manipulated hyperglycemia/hyperlipidemia and related genes expression in diabetic rats[J]. International Journal of Biological Macromolecules,2015(75):316 - 321. https://doi.org/10.1016/j.ijbiomac.2015.01.052.

41. Khillan J S. Vitamin A/ retinol and maintenance of pluripotency of stem cells[J]. Nutrients,2014,6(3):1209-1222. DOI:10.3390/nu6031209.

\section{Received 28.12.2020}

Reviewed 30.01.2021

\section{Revised 16.02.2021}

Approved 30.03.2021

Cite as Vancouver Citation Style

Wang H., Melnyk O., Li Bo. Functional drink technology with chia seeds. Grain Products and Mixed Fodder's, 2021; 21 (1, 81): $20-30$. DOI https://doi.org/

Cite as State Standard of Ukraine 8302:2015

Functional drink technology with chia seeds / Wang H. et al. // Grain Products and Mixed Fodder's. 2021. Vol. 21, Issue 1 (81). P. 20-30. DOI https://doi.org/ 